\title{
Epidemiological profile of individuals with American cutaneous leishmaniasis in Jequitinhonha Valley, Brazil
}

M.E. da Consolação Soares, ${ }^{7}$ A.L. Pedrosa-Silva, ${ }^{7}$ L. Sá e Rocha, ${ }^{1}$ N.L. Lima, ${ }^{7}$ F.D. Verli, ${ }^{7}$ F. de Oliveira Ferreira ${ }^{7}$ and S.A. Marinho ${ }^{7}$

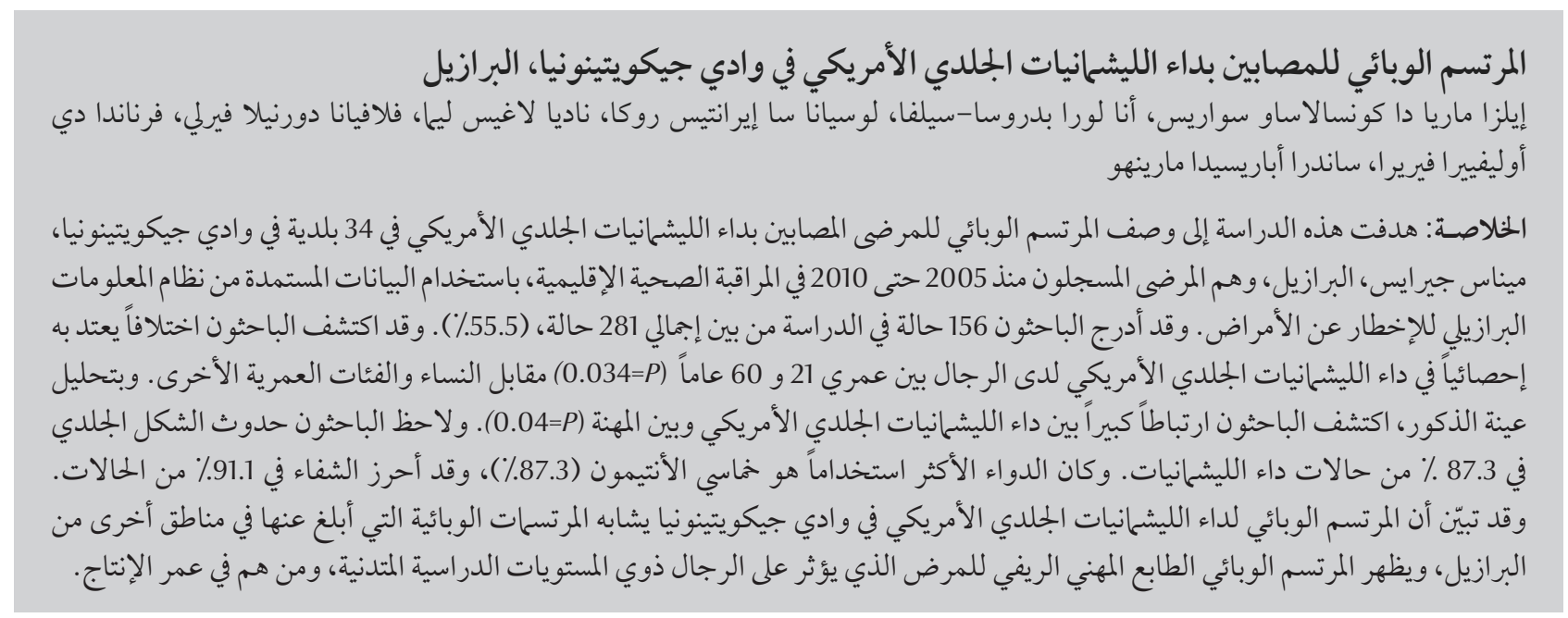

ABSTRACT This study aimed to characterize the epidemiological profile of patients with American cutaneous leishmaniasis (ACL) in 34 municipalities in Jequitinhonha Valley, Minas Gerais, Brazil, registered from 2005 to 2010 with the Regional Health Superintendence, using data from the Brazilian Disease Notification Information System. Among 281 cases, 156 (55.5\%) were included in the study. A statistically significant difference was found in ACL among men between 21 and 60 years of age $(P=0.034)$ in relation to women and other age groups. Analysing the male sample, a significant association was found between ACL and occupation $(P=0.04)$. The cutaneous form occurred in $87.3 \%$ of cases. The medication most often employed was pentavalent antimony $(87.3 \%)$, with cure achieved in $91.1 \%$ of cases. The epidemiological profile of ACL in the Jequitinhonha Valley is similar to that reported for other regions of Brazil, exhibiting a rural occupational nature and affecting men with low levels of schooling within the productive age.

Profil épidémiologique des personnes atteintes de leishmaniose cutanée américaine dans la vallée du Jequitinhonha (Brésil)

RÉSUMÉ La présente étude visait à dresser le profil épidémiologique de patients atteints de leishmaniose cutanée américaine dans 34 municipalités de la vallée du Jequitinhonha, dans l'État du Minas Gerais (Brésil), enregistrés entre 2005 et 2010 auprès de la Surintendance régionale de la santé, en utilisant les données du système brésilien de notification des maladies. Sur 281 cas, 156 (55,5 \%) ont été inclus dans l'étude. On a constaté une différence statistique significative chez les hommes âgés de 21 à 60 ans $(p=0,034)$ par rapport aux femmes et aux autres tranches d'âge. L'analyse de l'échantillon masculin a révélé une corrélation significative entre la maladie et le type d'emploi $(p=0,04)$. La forme cutanée concernait $87,3 \%$ des cas. Les médicaments le plus souvent utilisés étaient les antimoniés pentavalents (87,3\%), avec une guérison dans 91,1\% des cas. Le profil épidémiologique de la leishmaniose cutanée américaine dans la vallée du Jequitinhonha est similaire à celui observé dans les autres régions du Brésil : il montre que la maladie touche principalement les personnes ayant un emploi rural et les hommes de la tranche d'âge la plus productive qui ont un faible niveau d'études.

${ }^{1}$ Departamento de Ciências Básicas, Universidade Federal dos Vales do Jequitinhonha e Mucuri (UFVJM), Diamantina, Minas Gerais, Brazil (Correspondence to F.D. Verli:flavianaverli@gmail.com).

Received: 10/07/12; accepted: 27/11/12 


\section{Introduction}

American cutaneous leishmaniasis (ACL) is a zoonotic disease that affects humans as well as different wild and domesticated animal species [1]. The etiological agent of ACL is a protozoan belonging to the genus Leishmania. This organism has two evolutional forms during its biological cycle - one found in the digestive tube of the vector insect and another found in the tissues of vertebrate host [2,3].

Transmission is carried out by different species of phlebotomine insects [4]. Wild reservoirs include species of rodents, marsupials (opossum, kangaroo), xenarthrans (anteater, armadillo) and wild canines (wolf, fox) [3]. Humans can become infected by coming into contact with forest areas in which there are enzootic diseases caused by different species of Leishmania [4] or being stung by a transmitting insect. Transmission does not occur from person to person. Domestic dogs may also be infected with the disease [3].

$\mathrm{ACL}$ is a disease with chronic evolution that involves the skin and mucosa and may be either localized or diffuse [4]. Lesions predominantly affect uncovered parts of the body where insects bite and clinically present as erythematous papules that progress to vesicles and pustules before becoming scabs. After the scab falls off, an ulcer with high, infiltrated edges appears, the floor of which has salient, reddish granulations [5].

The cutaneous form is the most common clinical manifestation, with a single lesion or small number of exclusively cutaneous lesions that tend to heal. In rare cases, the lesions may be numerous, which is denominated disseminated cutaneous leishmaniasis [3]. Another clinical form is mucocutaneous leishmaniasis, in which the parasite produces destructive secondary lesions involving the mucosa and cartilage, appearing months or even years after the initial primary lesion. The most commonly affected anatomic structures are the nose, pharynx, mouth and larynx. The ulcerative process can affect the lips and propagate throughout the face, making it difficult for the patient to breathe, speak or eat. Moreover, respiratory complications often occur, which can lead to the death of the patient $[1,6]$.

The clinical-epidemiological diagnosis of leishmaniasis can be made based on the typical lesions of the disease, especially if the patient has visited or come from an endemic area [3]. Laboratory diagnosis is mainly based on the study of parasites in swabs from in vitro culture of the lesion following Giemsa staining. Montenegro intradermal reaction (MIDR) and histopathological and serological examinations can also be used [4]. The first drug of choice is pentavalent antimony ( $\mathrm{N}$-methylglucamine antimoniate) for 20-30 days. The side-effects of this drug include muscle pain, anorexia, nausea and vomiting. In severe cases, amphotericin B may be used as the second choice [3].

ACL is an important public health problem with ample distribution worldwide [2], occurring in 88 countries in Africa, the Americas, Asia and Europe. WHO estimates that 350 million people in the world are at risk, with records of approximately 2 million new cases per year [3]. The disease is currently undergoing geographic expansion and there has been a change in its epidemiological profile in recent decades. This is due to migration of the human population, the growth and disorderly urbanization of rural areas and environmental changes caused by mankind [7]. In Brazil, there are records of cases of $A C L$ in all regions of the country [3].

The aim of the present study was to characterize the epidemiological profile of individuals with ACL in 34 municipalities in the region of the Jequitinhonha Valley, state of Minas Gerais, Brazil, between 2005 and 2010 .

\section{Methods}

\section{Study area and design}

The study was carried out at the Regional Secretary of Health headquarters in the city of Diamantina, Minas Gerais, which encompasses 34 municipalities located in the upper and middle Jequitinhonha Valley, according to the Regionalization Plan for the Minas Gerais Secretary of Health [8]. Based on location, the cities were classified as pertaining to the upper (20 cities, including Diamantina) and middle (eight cities) Jequitinhonha Valley, following the course of the river by the same name. According to the Territorial Information System [9], six cities covered by the State Secretary of Health were not included in either territory and were considered isolated municipalities. Data from the Diamantina Municipal Secretary of Health and the Stomatology Clinic of the Universidade Federal dos Vales do Jequitinhonha e Mucuri (UFVJM) were also analysed.

\section{Data acquisition}

Information from the medical charts of individuals with a diagnosis of ACL was collected from the Regional Secretary of Health for the period from 2005 to 2010, using the epidemiological section of the Disease Notification Information System. Data were collected on epidemiological indicators (age group, sex, schooling, municipality and area of residence) and operational indicators (laboratory diagnosis, evolution of case, co-infection with HIV, use of medication, pregnancy, association of the disease with occupation, clinical form and relapses), based on the guidelines of the American cutaneous leishmaniasis control manual [3]. The time elapsed between diagnosis and the beginning of treatment and the month of notification was also recorded. Only medical charts that were duly filled out were included in the study, with exclusion of any chart in which one or more questions were unanswered. 


\begin{tabular}{|c|c|c|c|c|}
\hline Regions of Jequitinhonha & $\begin{array}{l}\text { Total population } \\
\text { (inhabitants) }\end{array}$ & $\begin{array}{l}\text { Cases } \\
\text { No. }\end{array}$ & $\begin{array}{c}\text { Prevalence rate } \\
\%\end{array}$ & $\begin{array}{c}\text { Mean Human } \\
\text { Development Index }\end{array}$ \\
\hline Upper $(n=20)$ & 255195 & 86 & 0.336 & 0.672 \\
\hline Middle $(n=8)$ & 108155 & 72 & 0.665 & 0.657 \\
\hline Other $(n=6)$ & 50834 & 0 & 0 & 0.659 \\
\hline Total $(n=34)$ & 414184 & 158 & 0.381 & 0.662 \\
\hline
\end{tabular}

Data on the cases notified by the Municipal Secretary of Health were recorded. The cases compiled at the Stomatology Clinic were analysed based on the following epidemiological indicators: anatomical site of the lesion in the oral mucosa; simultaneous occurrence of lesions in the oral mucosa and skin; biopsies performed; and whether cases had been notified in the Disease Notification Information System database.

\section{Statistical analysis}

SPSS version 17.0 was used for the tabulation of the data. Descriptive analysis was performed. The chi-square test and Fisher's exact test were used to establish significant differences $(P<0.05)$.

\section{Ethical considerations}

This study was carried out in compliance with the ethical aspects established by Resolution 196/96 of the Brazilian Board of Health for research involving human subjects. The Regional Secretary of Health authorized the study, following approval from the UFVJM Human Research Ethics Committee (process number 098/10).

\section{Results}

According to the Disease Notification Information System database, a total of 281 patients with ACL were registered with the Regional Secretary of Health. Of these, the charts of 158 (56.3\%) were correctly filled out based on the established criteria.

Among the 34 municipalities linked to the Regional Secretary of Health, 20 (54\%) had cases of ACL - 86 cases (54.4\%) in the region of the upper Jequitinhonha Valley and 72 (45.6\%) in the middle Jequitinhonha Valley. The greatest prevalence of ACL was found in the city of Araçuaí in the middle Jequitinhonha Valley (35 cases), followed by the city of Coluna in the upper Jequitinhonha Valley (28 cases). No cases of ACL were reported for the six municipalities that did not pertain to either territory.

The prevalence rate determined from the sum of the populations covered by the State Secretary of Health in the upper and middle Jequitinhonha Valley divided by the number of cases was $0.336 \%$ and $0.665 \%$, respectively (Table 1). The cities with the lowest prevalence rates were José Gonçalves de Minas in the middle Jequitinhonha Valley (3.51\%) and Coluna in the upper Jequitinhonha Valley (3.10\%). The majority of cases $(65.8 \%)$ occurred in 2007 and 2008 (Table 2). Within the time range studied, 2005 and 2006 had the lowest prevalence of ACL, accounting for only $2.6 \%$ of the total number of cases. In 2009 and 2010, the prevalence was $31.6 \%$. The period of the year with the greatest occurrence of the disease was from December to March (77 cases; $48.7 \%$ ), followed by August to November (49 cases; 31\%) and April to June $(32$ cases; $20.3 \%)(P<0.001)$.

The age of affected individuals ranged from 0 to 86 years, with 79 individuals (50\%) between 21 and 60 years of age (mean age 40.5 years). There was a greater prevalence of males $(n=45$; $57.7 \%)$ than females $(n=34 ; 42.6 \%)$ in this age range $(P=0.034)$ (Table 3$)$. With regard to ethnicity, there was a predominance of mulattoes (83 patients; $52.5 \%)$, with the remaining 73 patients (46.2\%) distributed among Caucasian, African descent and indigenous/Asian descent. In two cases (1.3\%) ethnicity was not informed on the chart.

Table 2 Frequency of American cutaneous leishmaniasis (ACL) cases identified in years 2005, 2006, 2007, 2008, 2009, 2010 in the Jequitinhonha Valley, Diamantina, Minas Gerais, Brazil, 2010

\begin{tabular}{lcc} 
Year & Number of patients (\%) & Cumulative percentage (\%) \\
2005 & $2(1.3)$ & 1.3 \\
2006 & $2(1.3)$ & 2.5 \\
2007 & $49(31)$ & 63.5 \\
2008 & $55(34.8)$ & 68.4 \\
2009 & $30(19.0)$ & 87.3 \\
2010 & $20(12.7)$ & 100.0 \\
\hline
\end{tabular}




$\begin{aligned} & \text { Table } 3 \text { Association between age and sex of individuals diagnosed with American cutaneous leishmaniasis (ACL), } \\
& \text { Diamantina, Minas Gerais, Brazil, } 2010\end{aligned}$
\begin{tabular}{lccc} 
Age (years) & Males & Females & Total \\
& No. $(\%)$ & No. $(\%)$ & No. (\%) \\
$0-20$ & $15(19.2)$ & $12(15.1)$ & $27(17.1)$ \\
$21-60$ & $45^{\mathrm{a}}(57.7)$ & $34^{\mathrm{a}}(42.6)$ & $79(50.0)$ \\
$\geq 61$ & $18(23.1)$ & $34(42.5)$ & $52(32.9)$ \\
\hline
\end{tabular}

${ }^{a}$ Chi-squared test, $P=0.034$.

Regarding schooling, the majority $(n=$ $110 ; 69.6 \%)$ was either illiterate $(n=29$; $26.36 \%)$ or had an elementary school education $(n=81 ; 73.64 \%)$. Among the remaining 48 patients (30.4\%), six (12.5\%) had a high school education, five (10.4\%) had a university education and the degree of schooling was unknown for 37 patients (77.1\%).

A significantly greater number of cases of ACL occurred in patients from rural areas $(n=116 ; 73.4 \%)$ in comparison with those from urban areas $(n=40$; $25.3 \%)(P<0.001)$; this information was unknown in two cases (1.3\%). An association between occupation and infection with ACL was observed in 25 cases (15.8\%), with no such association found in 103 patients $(65.2 \%)$; in 30 cases (19\%) this association was not investigated. In males, there was a statistically significant association between ACL and type of occupation $(P=0.04)$ (Table 4).

Regarding the appearance of the lesions, 139 (88\%) were new cases, 9 (5.7\%) were relapses and 5 (3.15\%) were transferences; in another five cases (3.15\%), this information was unknown because of transference. Transference was considered a move from one city to another by a patient with ACL. In the cases of relapse, there was no information on the location of the primary lesion. The cutaneous form was the most frequent clinical manifestation (138 cases; $87.3 \%$ ). With regard to relapses, $44.4 \%$ of cases exhibited mucosal lesions (Table 5); in all cases of relapse $(n=9)$, the patients were over 41 years of age and had a low level of schooling (Table 6).

For confirmation of the diagnosis of ACL, there was a predominance of laboratory examinations (121 confirmations; $76.6 \%$ ), with 36 cases (23.4\%) diagnosed through clinical-epidemiological examinations. MIDR was the most frequently performed complementary examination for the diagnosis of ACL (77 cases; 48.7\%). Parasitological examination was performed in 58 cases (36.7\%) and histopathological examination was performed in 29 cases (18.4\%). In some cases, more than one examination per patient was performed.

The vast majority of patients $(n=$ 142; 89.9\%) initiated treatment within approximately 30 days of diagnosis. Medicinal treatment was performed with pentavalent antimony in 138 patients (87.3\%), followed by amphotericin B (seven patients; $4.4 \%$ ); two patients (1.3\%) used other drugs and 11 (7\%) did not take medication. Pentavalent antimony was the drug used by all five pregnant women. Concomitant infection with HIV was reported in only five cases $(3.2 \%)$ of ACL; however, this information was not provided for $64 \mathrm{pa}$ tients (40.5\%). Among the five patients with HIV co-infection, two (40\%) used pentavalent antimony and three (60\%) used amphotericin B.

The most common evolution of the disease was cure (144 cases; 91.1\%). Death by other causes occurred in seven cases (4.4\%) and ACL was the cause of death in two patients (1.3\%). This information was not provided in five cases (3.2\%). All cases of relapse evolved toward cure.

Among the 11 cases registered with the Diamantina Municipal Secretary of Health, only two (18.2\%) were notified at the Regional Secretary of Health. Three cases of ACL were diagnosed at the UFVJM Stomatology Clinic; these patients were males from rural areas with a mean age of 51.6 years. The lesions only affected the oral mucosa (palate and gums, gums; and labial and buccal mucosa), with no concomitant skin lesions. The diagnosis was performed through histopathological examination following incisional biopsy of the lesions.

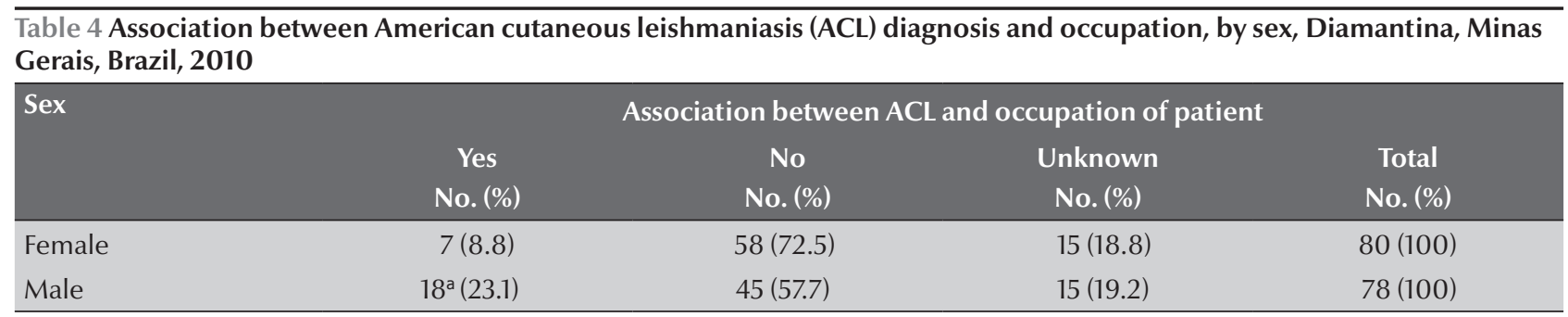

${ }^{a}$ Chi-squared test, $P=0.04$. 


\begin{tabular}{|c|c|c|c|c|}
\hline \multirow[t]{3}{*}{ Clinical form of lesion } & \multicolumn{4}{|c|}{ Type of input recorded in Disease Notification Information System } \\
\hline & Relapse & New case & Transference $^{\mathrm{a}}$ & Total \\
\hline & No. (\%) & No. (\%) & No. (\%) & No. (\%) \\
\hline Mucocutaneous & $0(0)$ & $2(40)$ & $3(60)$ & $5(3.2)$ \\
\hline Mucosal & $4(28.6)$ & $10(71.4)$ & $0(0)$ & $14(8.9)$ \\
\hline Cutaneous & $5(3.6)$ & $127(92)$ & $1(7)$ & $144(87.3)$ \\
\hline Unknown & $0(0)$ & $0(0)$ & $1(100)$ & $1(0.6)$ \\
\hline
\end{tabular}

${ }^{a}$ Transference refers to patient moving from one municipality to another.

\section{Discussion}

The city of Diamantina, headquarters of the Regional Secretary of Health, where the present study was carried out, is located in the Jequitinhonha Valley in the countryside of the state of Minas Gerais, Brazil. According to the Territorial Information System, this is one of the poorest regions in the country. The upper Jequitinhonha Valley has a greater rainfall index than the middle Jequitinhonha Valley, which explains the greater prevalence of cases in the former, where the summer was the period with the greatest incidence of notifications $[10,11]$. A greater number of phlebotomine insects gather in warm, wet seasons [12] and consequently there is a greater incidence of the disease. Moreover, the vast majority of relapses (88.9\%) occurred in the upper Jequitinhonha Valley. However, these data should be considered with caution as the proximity to the headquarters facilitates notifications of disease. Nonetheless, the prevalence rate demonstrates that cities covered by the State Secretary of Health located in the middle Jequitinhonha Valley had nearly twice the number of cases per thousand inhabitants compared with those in the upper Jequitinhonha Valley. The city with the highest ACL prevalence rate $(3.5 \%)$ is also located in the middle Jequitinhonha Valley. This may be related to the lesser development of this region, the cities of which have a lower mean Human Development
Index (0.657) than those of the upper Jequitinhonha Valley (0.672) [9]. The city of Diamantina is located in the upper Jequitinhonha Valley, which explains the greater degree of development and greater access of patients in the cities of this microregion.

The greatest number of cases was reported in 2007 and 2008, with decreasing figures in the subsequent years. There is currently a reduction in cases of ACL throughout Brazil, as the mean annual number of cases between 1994 and 2005 was 30.384, dropping to 21.417 in 2006 and 2007 [13]. This reduction is related to the implementation of the American Cutaneous Leishmaniasis Surveillance Programme promoted by the Ministry of Health, the aim of which is the early diagnosis and treatment of cases in order to reduce the deformities caused by the disease. With this programme, suspected cases are submitted for clinical, epidemiological and laboratory examinations and, if confirmed, are notified in the Disease Notification Information System [3]. Treatment is instituted, with a 12-month follow-up period after cure. It should be stressed that ACL is an important public health problem in Brazil due to its magnitude and the risk of deformities, which have social and economic consequences. This disease is therefore considered to have an occupational nature [3].

Individuals between 20 and 50 years of age are at greater risk of contracting ACL due to their labour activities, especially in the fields of agriculture and extractivism [11]. In the present study, males between 21 and 60 years of age had a significantly higher prevalence of ACL compared with females and other age groups. Analysing the male sample alone, an association was found between ACL and type of occupation, as patients from rural areas were the most affected [14-18], thereby confirming the occupational nature of the disease [3]. However, a previous study discussed the emergence of a change in the epidemiological profile of ACL, which can affect individuals regardless of sex, age, type of occupation or place of residence $[18,19]$.

A low level of schooling was also associated with ACL. Moreover, the majority of relapses occurred among individuals with no higher than an elementary school education. According to Guerra et al. [11], low levels of schooling and income as well as the predominance of occupations that require little qualification demonstrate that, like most infectious-parasitic disease, ACL mainly affects poorer populations.

Immunodepression stemming from HIV is another facilitating factor in the progression of ACL, as the dissemination of the cutaneous form of the disease and involvement of organs (visceralization of ACL) rarely occur in immunocompetent patients. This fact is important to health care professions, as ACL mucosal lesions can overlap and mask those stemming 


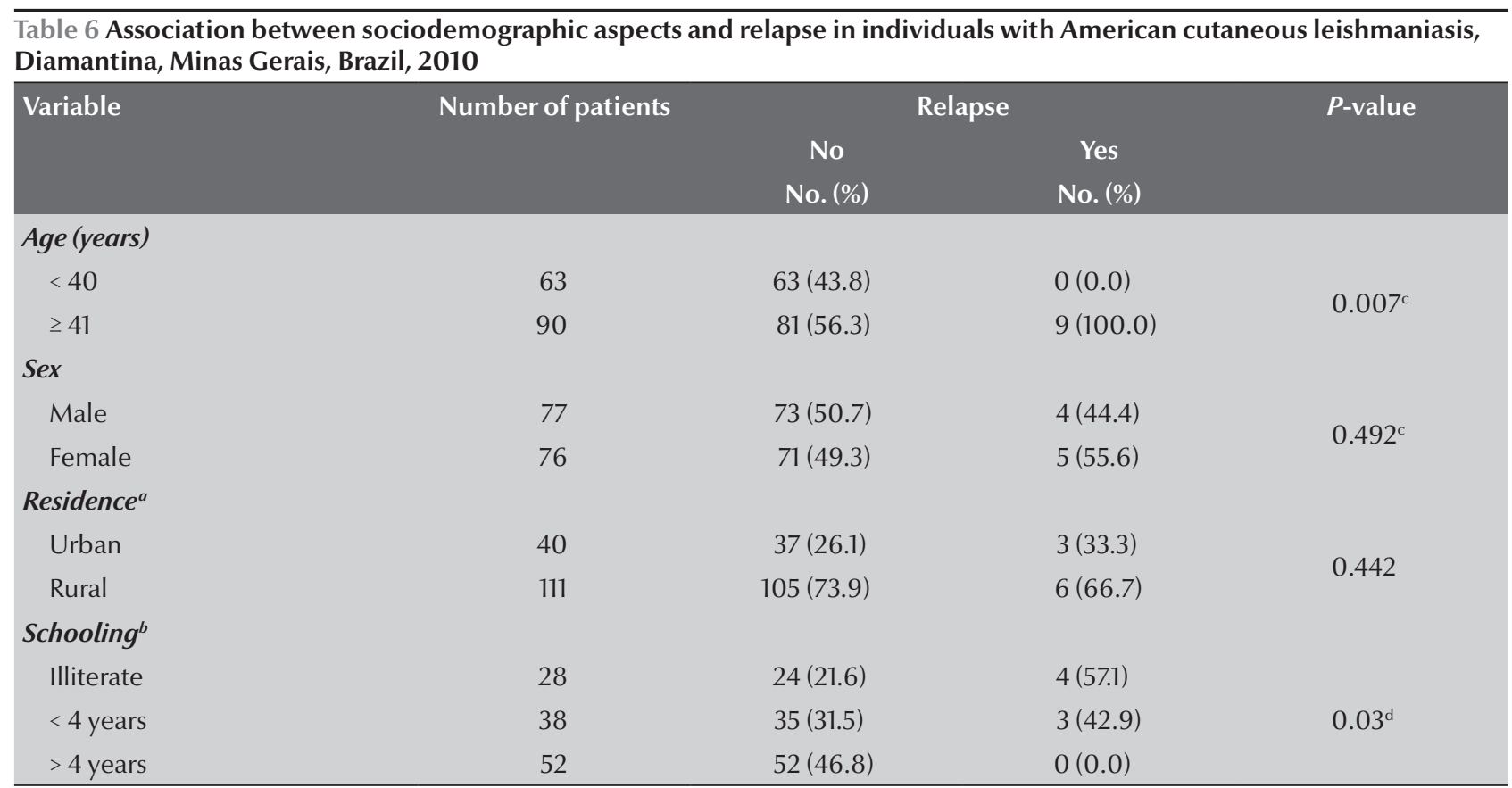

${ }^{a}$ Two cases in which residence was not investigated; ${ }^{b} 35$ cases in which schooling was not recorded. ${ }^{c}$ Fisher exact test; ${ }^{d}$ Chi-squared test.

from Kaposi's sarcoma or herpes in HIV-positive patients. Serology for HIV is recommended for all patients with ACL, regardless of age [20]. However, the possible co-infection with HIV was not considered important in the cases analysed in the present study, as the option "unknown" was marked on this item in $40.5 \%$ of cases.

The diagnosis of ACL encompasses epidemiological, clinical and laboratory aspects and often involves a combination of these elements $[4,21]$. In endemic areas, the diagnosis is most often clinical-epidemiological [3], which is subject to errors that could be minimized with the aid of laboratory examinations [22]. In the present study, most diagnoses were confirmed by laboratory examinations. The first test of choice was MIDR, which is founded on the immune response of the retarded cell hypersensitivity [20]. However, this can be negative in the first 4-6 weeks following the emergence of a skin lesion and generally persists as positive after treatment. Patients with mucosal leishmaniasis generally have an exacerbated MIDR and those with the diffuse cutaneous form have a negative MIDR [3]. For the diagnosis, histopathological examinations (haematoxylin-eosin and the use of antibodies labelled with immunoperoxidase for the detection of the parasite), in vitro and in vivo culture, serology (immunofluorescence, enzyme-linked immunosorbent assay and direct agglutination) and polymerase chain reaction can achieve satisfactory results [4]. All patients at the Stomatology Clinic were diagnosed through histopathological examinations.

Cutaneous was the most prevalent clinical form, which corroborates the findings of previous studies $[23,24]$. The mucosal type was found in a smaller number of patients but should nevertheless be considered due to the fact that this form is reported to have a greater number of relapses $[23,25-27]$. However, in the present study there was a slight predominance of relapses in the cutaneous form (five cases) over the mucosal form (four cases).
Following diagnosis of ACL, the majority of treatments were initiated within 30 days. This finding is related to the high percentage of cures in the present sample, demonstrating that early diagnosis and treatment is essential to the positive evolution of cases $[20,28]$. The first drug of choice was pentavalent antimony, used in the majority of patients parenterally, with the dose ranging from 10 to $20 \mathrm{mg} / \mathrm{Sb}^{5} / \mathrm{kg} /$ day for 30 days, which is the standard protocol recommended by WHO. Pentavalent antimony is indicated for all forms of ACL, although the mucosal and mucocutaneous forms have a slower response and a greater possibility of relapse $[10,21,28]$. However, this medication is contraindicated for pregnant women, as it crosses the placenta barrier, affecting the nervous tissue of the fetus and leading to severe mental retardation or miscarriage [21]. Despite this, all pregnant women analysed in the present study received pentavalent antimony, risking the health of the unborn child, rather than amphotericin B or pentamidine, which were the second drugs 
of choice. Restricted use of pentavalent antimony is recommended for patients co-infected with HIV, those over 50 years of age or those with heart, liver or kidney disease. The treatment of such patients should be conducted with caution, with a previous heart examination and weekly follow-up due to the side-effects and toxicity of the medication as well as the possibility of the parasite developing resistance to the drug [20].

The Municipal Secretary of Health has the function of notifying and referring cases diagnosed in the respective city of origin to the Regional Secretary of Health for notification in the Disease Notification Information System. However, this process did not occur in $81.8 \%$ of cases registered with municipal secretaries of health. As a result, there was a considerable degree of undernotification in the city of Diamantina, where the headquarters of the Regional Secretary of Health is located, which likely occurred with other municipal secretaries of health in the region.

The three cases diagnosed at the UFVJM Stomatology Clinic were the mucosal form and located in the oral cavity, without nasal involvement. However, this form most often affects the nasal mucosa, compromising the septum, followed in order of frequency by the oral mucosa. In both conditions, there is considerable risk of permanent deformity. In the present study, there were no cases of concomitant cutaneous lesions. This explains why these patients sought the Stomatology Clinic, which is a reference service for the diagnosis of oral lesions in the region. As with the cases of cutaneous leishmaniasis, there was a greater prevalence of adult males from rural areas in the mucosal cases. In the three cases analysed, the palate, gums, labial mucosa and buccal mucosa were affected. The involvement of mucosa other than that of the upper airway is rare $[21,22]$. Mucosal leishmaniasis (espundia) is difficult to treat and has a reserved prognosis with regard to the possibility of a cure. The frequency of this form has been diminishing in endemic areas, likely due to early diagnosis and treatment $[14,21,23]$, as this form is nearly always secondary to skin lesions. It may emerge with the skin lesion in activity or years after its healing, making it a mucocutaneous form. A large portion of patients with mucosal leishmaniasis have scars indicative of previous cutaneous leishmaniasis, whereas others do not have suggestive lesions; in such cases, it is supposed that the initial lesion had been fleeting [3]. On the medical charts from the Stomatology Clinic analysed in the present study, there was no information on previous cutaneous scars, which would certainly indicate that the mucosal form could be a relapse of the disease. The factors that contribute toward the cutaneous form evolving into the mucosal form may stem from delayed healing of the primary lesion and inadequate initial treatment $[13,29]$.

The diagnosis of ACL should be based on the clinical and epidemiological data of the patient in combination with laboratory examinations. After diagnosing cases of ACL, health care professionals have the responsibility of referring these cases to the Municipal Secretary of Health of the city of origin, as this disease is one of mandatory notification [3]. Treatment should be initiated as early as possible, with rigorous follow-up, especially for those patients with contraindication or restrictions to the medication. Moreover, educational actions should be prioritized, with an emphasis on prevention, followed by actions directed toward the correct diagnosis and early treatment. Efforts should be made to improve the quality of the care offered, diagnosis and notification. Greater training and awareness on the part of health care professionals is needed in order for these professionals to give adequate importance to the role of information in health care and improve the quality of the records of procedures on medical charts.

\section{Conclusion}

The pattern of ACL in the upper and middle Jequitinhonha Valley is similar to that reported for other regions of Brazil. This disease continues to exhibit a rural occupational nature, but with an increase in incidence in urban areas. There is a predominance of diagnoses and notifications in warm, wet periods of the year. Males within the productive age range are the most affected but women also account for a considerable number of cases. The cutaneous form is the most frequent and MIDR is the most commonly used laboratory examination for the confirmation of the diagnosis. For lesions in the oral mucosa, incisional biopsy is the most often performed examination. The treatment of choice is pentavalent antimony, with some restrictions, and cure is the most common evolution of the disease.

\section{Acknowledgements}

The authors are grateful to Mr José Vicente Honorato, head of the epidemiological sector of the Regional Health Superintendence, Ms Ione de Fátima Pereira, Diamantina Municipal Secretary of Health and Professor Esmeralda Maria da Silveira, head of the UFVJM Stomatology Clinic, for making available the information contained on the medical charts at this clinic. The authors thank Coordenah ção de Aperfeiçoamento de Pessoal de Nivel Superior (CAPES) for their financial support.

Funding: The study was funded by Coordenação de Aperfeiçoamento de Pessoal de Nível Superior (CAPES).

Competing interests: None declared. 


\section{References}

1. Neves DP. Parasitologia humana, 10th ed. São Paulo, Editora Atheneu, 2004.

2. Falquete A, Sessa AP. Leishmaniose tegumentar americana. In: Veronesi R, Focaccia, R, eds. Tratado de infectologia, 2nd ed. São Paulo, Editora Atheneu, 2004.

3. Manual de vigilância da leishmaniose tegumentar Americana, 2nd ed. Brasília, Ministério da Saúde, Secretaria de Vigilância em Saúde, 2007.

4. Basano AS, Camargo, LMA. Leishmaniose tegumentar americana: histórico, epidemiologia e perspectivas de controle. Revista Brasileira de Epidemiologia, 2004, 7:328-337.

5. Rouquayrol MZ. Epidemiologia e saúde, 3rd ed. Rio de Janeiro, Editora Medsi, 1988.

6. Sampaio RNR, Paula CDR. Leishmaniose tegumentar americana no Distrito Federal. Revista da Sociedade Brasileira de Medicina Tropical, 1999, 32:523-528.

7. São Paulo. Secretaria do Estado de São Paulo. Aspectos epidemiológicos da leishmaniose tegumentar americana no município de Ubatuba, litoral de São Paulo, Brasil, 1993-2009. Revista de Saúde Pública, 2004, 38:331-332.

8. Plano Diretor de Regionalização de Minas Gerais (PDR). Minas Gerais, Secretaria de Estado de Saúde (http://www.saude. mg.gov.br/index.php?option=com_gmg\&controller=docume nt\&id=9242, accessed 18 June 2010).

9. Brasil, Ministério do Desenvolvimento Agrário. Secretaria de Desenvolvimento Territorial, Sistema de Informações Territoriais (http://sit.mda.gov.br/territorio.php?menu=territorio\&b ase $=1$ \&informe $=\mathrm{s}$, accessed 18 June 2010).

10. Moreira RCR et al. Nível de conhecimentos sobre leishmaniose tegumentar americana (LTA) e uso de terapias alternativas por populações de uma área endêmica da Amazônia do Maranhão, Brasil. Cadernos de Saúde Pública, 2002, 18:187-195.

11. Guerra JAO et al. Epidemiologia da leishmaniose tegumentar na Comunidade de São João, Manaus, Amazonas, Brasil. Cadernos de Saúde Pública, 2006, 22:2319-2327.

12. Teodoro $U$ et al. Influência da reorganização, da limpeza do peridomicílio e da desinsetização de flebotomíneos no Município de Doutor Camargo, Estado do Paraná, Brasil. Cadernos de Saúde Pública, 2003, 19:1801-1813.

13. Atlas de leishmaniose tegumentar Americana: diagnósticos clínico e diferencial. Brasil, Ministério da Saúde, Secretaria de Vigilância em Saúde, Departamento de Vigilância. Epidemiológica, 2006:136-136.

14. Araújo NS et al. Aspectos clínicos e histopatológicos da leishmaniose tegumentar americana em pacientes atendidos no Hospital de Clínicas da Universidade Federal de Uberlândia, MG, Brasil. Revista de Patologia Tropical, 2008, 37:23-31.

15. Ampuero J, Macêdo V, Marsden P. Características clínicas da leishmaniose tegumentar em crianças de 0 a 5 anos em uma área endêmica de Leishmania (Viannia) braziliensis. Revista da Sociedade Brasileira de Medicina Tropical, 2006, 39:22-26.

16. Caldas AJM et al. Infecção por Leishmania (Leishmania) chagasi em crianças de uma área endêmica de leishmaniose visceral americana na Ilha de São Luís-MA, Brasil. Revista da Sociedade Brasileira de Medicina Tropical, 2001, 34:445-451.

17. Lima $\mathrm{C}$ et al. Observações sobre leishmaniose tegumentar, cinco anos após profilaxia. Revista de Saúde Pública, 1988, 22:73-77.

18. Oliveira CCG et al. Changing epidemiology of American cutaneous leishmaniasis $(\mathrm{ACL})$ in Brazil: a disease of the urban-rural interface. Acta Tropica, 2004, 90:155-162.

19. Gontijo CMF et al. Epidemiological studies of outbreak of cutaneous leishmaniases in the Rio Jequitinhonha Valley, Minas Gerais, Brazil. Acta Tropica, 2002, 81:143-150.

20. Guia de vigilância epidemiológica, 6th ed. Brasília, Ministério da Saúde, Secretaria de Vigilância em Saúde, 2005.

21. Gontijo B, Carvalho MLR. Leishmaniose tegumentar americana. Revista da Sociedade Brasileira de Medicina Tropical, 2003, 36:71-80.

22. Silveira TGV et al. Observações sobre o diagnóstico laboratorial e a epidemiologia da leishmaniose tegumentar no Estado do Paraná, sul do Brasil. Revista da Sociedade Brasileira de Medicina Tropical, 1999, 32:413-423.

23. Murback NDN et al. Leishmaniose tegumentar americana: estudo clínico, epidemiológico e laboratorial realizado no Hospital Universitário de Campo Grande, Mato Grosso do Sul, Brasil. Anais Brasileiros de Dermatologia, 2011, 86:55-63.

24. Passos VMA et al. Leishmaniose tegumentar na Região Metropolitana de Belo Horizonte: aspectos clínico, laboratoriais, terapêuticos e evolutivos (1989-1995). Revista da Sociedade Brasileira de Medicina Tropical, 2001, 34:5-12.

25. Corte AA et al. Aspectos eco-epidemiológicos da leishmaniose tegumentar americana no Município de Campinas. Cadernos de Saúde Pública, 1996, 12:465-472.

26. Stolf $\mathrm{HO}$ et al. Surto de leishmaniose tegumentar americana em Itaporanga. Revista do Instituto de Medicina Tropical de São Paulo, 1993, 35:437-442.

27. Carvalho et al. Leishmaniose tegumentar no Estado de Mato Grosso (Brasil): estudo clínico, laboratorial e terapêutico. Anais Brasileiros de Dermatologia, 2002, 77:45-56.

28. Oliveira-Neto MP et al. American tegumentary leishmaniasis (ATL) in Rio de Janeiro State, Brazil: main clinical and epidemiologic characteristics. International Journal of Dermatology, 2000, 39:506-514.

29. Costa J et al. Estado atual da leishmaniose cutânea difusa (LCD) no Estado do Maranhão: aspectos epidemiológicos e clínicoevolutivos. Revista da Sociedade Brasileira de Medicina Tropical, 1992, 25:115-123. 